\title{
Flux and transmission of $\beta$-casein during cold microfiltration of skim milk subjected to different heat treatments
}

\author{
Justyna Zulewska, ${ }^{1}$ Jarosław Kowalik, and Bogdan Dec \\ Department of Dairy Science and Quality Management, Faculty of Food Sciences, University of Warmia and Mazury, 10-719 Olsztyn, Poland
}

\begin{abstract}
Raw skim milk was subjected to different heat treatments: thermization $\left(65^{\circ} \mathrm{C}, 20 \mathrm{~s}\right)$, pasteurization $\left(72^{\circ} \mathrm{C}\right.$, $15 \mathrm{~s}$ ), and no heat treatment (milk was microfiltered using $1.4-\mu \mathrm{m}$ membranes at $50^{\circ} \mathrm{C}$ for bacteria removal; $1.4 \mathrm{MF}$ ). The milk (thermized, pasteurized, and 1.4 $\mathrm{MF}$ ) was cooled and stored at $2^{\circ} \mathrm{C}$ until processing (at least $24 \mathrm{~h})$ with cold $\left(\sim 6^{\circ} \mathrm{C}\right)$ microfiltration using a benchtop crossflow pilot unit (Pall Membralox XLAB 5, Pall Corp., Port Washington, NY) equipped with $0.1-\mu \mathrm{m}$ nominal pore diameter ceramic Membralox membrane (ET1-070, $\alpha$-alumina, Pall Corp.). The flux was monitored during the process, and $\beta$-casein transmission and removal were calculated. The study aimed to indicate the conditions that should be applied to maximize $\beta$-casein passage through the membrane during cold microfiltration $\left(5.6 \pm 0.4^{\circ} \mathrm{C}\right)$ of skim milk. The proper selection of heat treatment parameters (temperature, time) of the feed before the cold microfiltration process will increase $\beta$-casein removal. It is not clear whether the difference in $\beta$-casein transmission between 1.4 MF, thermized, and pasteurized milk results from the effect of heat treatment conditions on $\beta$-casein dissociation from the casein micelles or on passage of $\beta$-casein through the membrane. The values of the major parameters (permeation flux and tangential flow velocity, through the wall shear stress) responsible for a proper membrane separation process were considerably lower than the critical values. It seems that the viscosity of the retentate has a great effect on the performance of the microfiltration membranes for protein separation at refrigerated temperatures.
\end{abstract}

Key words: $\beta$-casein, cold microfiltration, flux

\section{INTRODUCTION}

Casein content of bovine milk represents approximately $80 \%$ of milk proteins. The principal casein frac-

Received January 25, 2018.

Accepted August 17, 2018.

${ }^{1}$ Corresponding author: justyna.zulewska@uwm.edu.pl tions are $\alpha_{\mathrm{S}^{-}}, \alpha_{\mathrm{S}^{-}}, \beta$-, and $\kappa$-casein, and their relative proportion is estimated to be $45.0,12.0,35.0$, and $8.0 \%$, respectively (Farrell et al., 2004). Caseins and calcium phosphate form stable casein micelles, which range in diameter from 15 to $600 \mathrm{~nm}$, with a weight average diameter of $180 \mathrm{~nm}$. At $4^{\circ} \mathrm{C}, \beta$-casein exists in solution as monomers of molecular mass $25 \mathrm{kDa}$ (Fox and McSweeney, 1998) and disassociates from the casein micelle (Davies and Law, 1983; Famelart et al., 1989) with decreasing temperature from 50 to $4^{\circ} \mathrm{C}$.

Several approaches have been developed to isolate $\beta$-casein from skim milk. Because $\beta$-casein dissociates from the casein micelles at $4^{\circ} \mathrm{C}$, cold microfiltration (MF) has been used to produce $\beta$-casein enriched fractions (Terre et al., 1987; Woychik, 1992). During MF using membranes with about $0.1-\mu \mathrm{m}$ pore size, milk constituents of a size smaller than the pores of the membrane pass through it into the permeate fraction. This include serum proteins, small micelles, and free $\beta$-casein that dissociated from the casein micelles at low temperature (Woychik, 1992). Use of cold MF has been successfully adapted to fractionate caseins from skim milk by Terre et al. (1987), Woychik (1992), and Van Hekken and Holsinger (2000).

A very comprehensive review of methods for $\beta$-casein isolation was recently published by Atamer et al. (2017). Among other methods is a method patented by Le Magnen and Maugas (1995) for obtaining $\beta$-casein by separating it from $\kappa$-casein involving the use of rennet casein. Huppertz et al. (2006) also developed a process to isolate $\beta$-casein from rennet-coagulated skim milk. Such methods offer a high-purity product (i.e., $\sim 90 \%$ in relation to the total protein material in the first method) but make it impossible to combine different fractions of casein to obtain products with altered functional, physiological, and nutritional characteristics. Cold MF seems to bring several opportunities, but a better understanding of factors influencing process yield and selectivity is needed.

The conditions used during the process of MF are crucial for the composition and the properties of the obtained fractions (Zulewska et al., 2009). Factors that influence the MF process of $\beta$-casein separation include 
high recirculation velocity of the retentate (at least 6 $\mathrm{m} / \mathrm{s}$ ), the smoothness of the membrane surface (Maubois and Ollivier, 1992), and maintenance of low temperatures $\left(2-6^{\circ} \mathrm{C}\right)$ in the MF equipment (Woychik, 1992; Le Berre and Daufin, 1994). Also, pH, ionic strength, and protein concentration showed to have a great effect on solubilization of $\beta$-casein and purity of obtained fractions. Pouliot et al. (1994) studied $\beta$-casein solubilization from native phosphocaseinate in the conditions of cold storage as affected by different $\mathrm{pH}$ levels, calcium chelation, and ionic strength and showed that the best conditions for producing $\beta$-casein-rich fractions $(90 \%$ of recovery) are $0^{\circ} \mathrm{C}, \mathrm{pH} 5.2,9.0 \mathrm{~g} / \mathrm{kg}$ of $\mathrm{NaCl}$, and $1.6 \mathrm{~g} /$ $\mathrm{kg}$ of trisodium citrate. Pierre and Brulé (1981) showed that the solubilization of $\beta$-casein from micelles in milk had an optimum at a protein concentration of $30 \mathrm{~g} / \mathrm{L}$ of total milk proteins. Although several publications deal with cold MF of skim milk to separate $\beta$-casein, the process needs further investigation to specify the best conditions for separation. The objectives of our research were to determine whether transmission and removal of $\beta$-casein through ceramic MF membranes at low temperature are affected by subjecting the milk to different heat treatments before the MF process and to monitor the flux changes during the cold MF process.

\section{MATERIALS AND METHODS}

\section{Experimental Design and Statistical Analysis}

Raw milk (about $60 \mathrm{~kg}$ ) was collected from the University of Warmia and Mazury (UWM) Experimental Station in Bałdy, Poland, and transported to the University's Dairy Research and Development Center. Then, raw milk was separated in the dairy technological hall at $45^{\circ} \mathrm{C}$ using a model LWG20 centrifuge (Spomasz, Gniezno, Poland). The raw skim milk was split into 3 batches: one portion $(\sim 20 \mathrm{~kg})$ was thermized $\left(65^{\circ} \mathrm{C}, 20 \mathrm{~s}\right)$, the second portion $(20 \mathrm{~kg})$ was pasteurized $\left(72^{\circ} \mathrm{C}, 15 \mathrm{~s}\right)$, and the third portion $(\sim 4 \mathrm{~kg})$ was microfiltered using $1.4-\mu \mathrm{m}$ membranes at $50^{\circ} \mathrm{C}$ for bacteria removal with no thermal treatment (1.4 $\mathbf{M F})$. Thermization and pasteurization processes were carried out with a plate heat exchanger (model P20-HB; Alfa Laval, Lund, Sweden). Skim milk was microfiltered using a benchtop crossflow pilot unit (Pall Membralox XLAB 5, Pall Corp., Port Washington, NY; Figure 1). The system was equipped with a $1.4-\mu \mathrm{m}$ nominal pore diameter ceramic membrane (ET1-070, $\alpha$-alumina; Pall Corp.). The milk (thermized, pasteurized, and 1.4 MF) was cooled and stored at $2^{\circ} \mathrm{C}$ until processing (at least $24 \mathrm{~h}$ ). Then, one batch of milk was cold microfiltered (average temperature during processing was $6^{\circ} \mathrm{C}$ ) using the same system as described above, equipped with 0.1- $\mu \mathrm{m}$ nominal pore diameter ceramic Membralox (ET1070, $\alpha$-alumina, Pall Corp.) membrane. The processing for each replicate was done over a 4-d period. Each individual variable was processed on a different day starting from d 2, whereas heat treatments and 1.4 MF processing were carried out on $\mathrm{d} 1$. The experiment was replicated 4 times, and the order of processing with different milks was rotated from one replicate to the next so that the average time of different (1.4 MF, thermized, pasteurized) milk storage before cold MF was the same for the 4 replicates. The initial parameters of milk storage were chosen based on the results of Ali et al. (1980), especially in relation to time of storage. To determine whether there were significant differences when processing 1.4 MF, thermized, and pasteurized skim milk with cold MF, all data were analyzed by ANOVA using Statistica (version 13.1, 1984-2016, StatSoft Inc., Tulsa, OK).

\section{MF of Milk for Bacteria Removal}

A benchtop crossflow pilot MF system (Pall Membralox XLAB 5, Pall Corp.) equipped with 1.4- $\mu \mathrm{m}$ nominal pore diameter ceramic membrane (ET1-070, $\alpha$-alumina; Pall Corp.) with surface area of $0.005 \mathrm{~m}^{2}$ was used. The membrane in a tubular single stainless steel module was monochannel with a 7 -mm channel diameter. The MF system was equipped with a recirculation pump (progressive cavity pump with frequency converter; Pall Corp.). The frequency converter was adjusted to 6 on a 0 -to-10 scale, which corresponds to

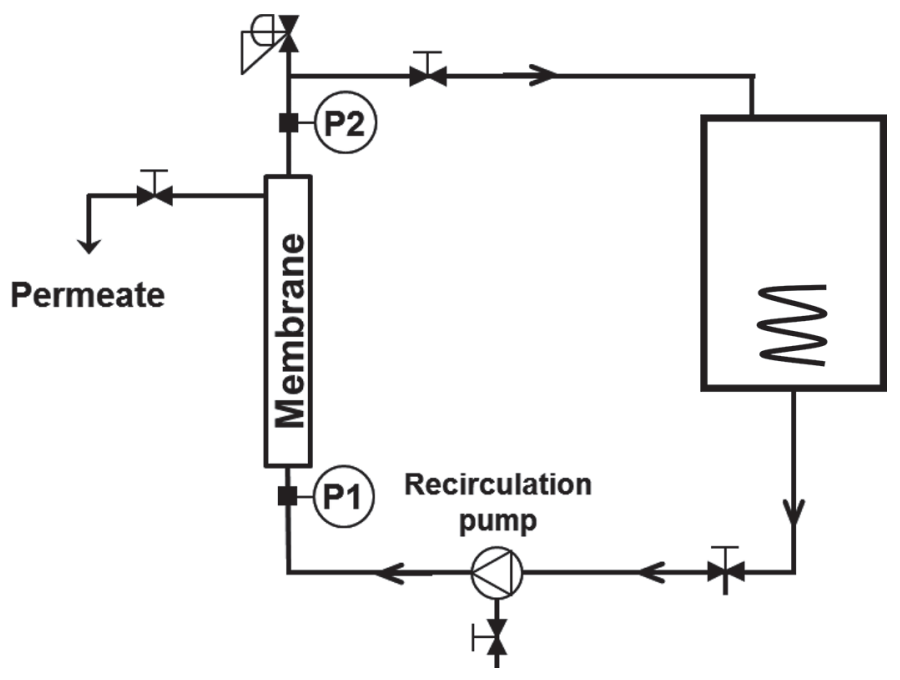

Figure 1. The ceramic microfiltration system used for microfiltration with a $1.4-\mu \mathrm{m}$ membrane at $50^{\circ} \mathrm{C}$ for bacteria removal or with a $0.1-\mu \mathrm{m}$ membrane at $9^{\circ} \mathrm{C}$ for protein fractionation. During processing, the temperature, retentate pressure inlet $(\mathrm{P} 1)$, and retentate pressure outlet (P2) were measured every $20 \mathrm{~min}$. Retentate and permeate were collected and weighed continuously during processing. 
approximately $6 \mathrm{~m} / \mathrm{s}$ linear velocity. The membrane was $250 \mathrm{~mm}$ long and was mounted vertically in the MF system. Permeate was removed at the top of the vertical membrane module. The pressure was adjusted using a retentate recirculation valve to maintain 120 $\mathrm{kPa}$ at the inlet of the membrane. This resulted in an outlet retentate pressure of about $100 \mathrm{kPa}$. This pressure range was recommended by the producer of the membrane. To stop the system, first the frequency converter was set at 0 , the pump was turned off, the system was drained using 2 drain valves, and the permeate outlet valve was closed. To start the system, the pump was turned on, the frequency converter was slowly adjusted to 6 , and the permeate valve was slowly opened (unless indicated otherwise). The MF system operated only in batch mode. The MF unit was combined with 2 water baths (Lauda Dr. R. Wobser GmbH and Co. KG, Königshofen, Germany), one for heating (model Alpha A 24) and the second for cooling (model Alpha RA 24) the system. The hot or cold water circulated in the water jacket of the feed tank. Additionally, a helical glass element was inserted inside the feed tank with hot or cold water circulating inside. A schematic diagram of the MF unit used in the experiment is shown in Figure 1.

Immediately before the processing, the MF system was cleaned. The storage solution $(0.55 \% \mathrm{vol} / \mathrm{vol}$ solution nitric acid) was flushed out of the system with room-temperature reverse-osmosis ( $\mathbf{R O}$ ) water until the $\mathrm{pH}$ was neutral. The MF system was heated with $\mathrm{RO}$ water up to $70^{\circ} \mathrm{C}$, and then a sodium hydroxide solution $(1.5 \% \mathrm{wt} / \mathrm{vol})$ was added to the water to reach $\mathrm{pH}$ 11. The alkaline solution was recirculated for $30 \mathrm{~min}$. After the cleaning, the MF system was flushed with RO water, initially at $70^{\circ} \mathrm{C}$ and then cooled slowly $\left(<10^{\circ} \mathrm{C} /\right.$ $\min$ ) to room temperature. The MF system was flushed with room-temperature $\mathrm{RO}$ water until neutral $\mathrm{pH}$ was reached. Then, the initial clean water flux (CWF) was determined at room temperature $\left(\sim 20^{\circ} \mathrm{C}\right)$. The water flux was calculated based on the weight of permeate collected in $60 \mathrm{~s}$ and the total membrane surface area. The following conditions were applied during water flux measurement: the retentate outlet valve was opened to produce the retentate inlet pressure of $120 \mathrm{kPa}$, and the permeate outlet valve was fully open. The alkaline cleaning was very important to restore the flux. When CWF was measured for the membrane rinsed with RO water after acidic storage, the flux value was much lower compared with the values for the measurement done after alkaline cleaning. The CWF measured after acidic storage was almost half of that obtained after alkaline cleaning and $\mathrm{RO}$ water rinsing (data not shown).

Raw skim milk $(3,768 \mathrm{~g})$ was concentrated at $50^{\circ} \mathrm{C}$ using a benchtop crossflow pilot MF system (Pall
Membralox XLAB 5, Pall Corp.) described above. The raw skim milk was placed in the feeding tank with all valves closed except the retentate valve. The pump was turned on, the frequency converter was adjusted to 6 , and the pressure was adjusted with the retentate valve to $120 \mathrm{kPa}$ at the inlet end of the membrane. The milk was recirculated for $5 \mathrm{~min}$ and then the permeate valve was slowly opened. The permeate was collected and the retentate was recirculated in the system. The flux $(\mathrm{kg} /$ $\mathrm{m}^{2}$ per hour) was determined every $10 \mathrm{~min}$ and was calculated based on the weight of permeate collected in $10 \mathrm{~min}$ and the total membrane surface area. At the end of the MF run, all retentate (the retentate was drained from the system by opening 2 valves) and all permeate collected from the processing run were mixed and each was sampled. The permeate consisted of 1.4 MF milk and after sampling was cooled and stored at $2^{\circ} \mathrm{C}$ until processing (at least $24 \mathrm{~h}$ ). The average total time of milk processing was about 148 min. Our plan was to carry out the process until 5 to $10 \%$ of initial skim milk remained in the system, accounting for 3.4 to $3.5 \mathrm{~kg}$ of permeate. However, in practice the process was carried out until the satisfactory flux was kept (on average $45 \mathrm{~kg} / \mathrm{m}^{2}$ per hour). The flux at the end of the process accounted for $20 \%$ of the initial process flux.

Immediately after processing, room-temperature RO water was flushed through the system. The retentate valve was opened to create an inlet retentate pressure of $120 \mathrm{kPa}$, and the permeate valve was fully open. The MF system was flushed until no milk was visible in the flush water on the retentate side. When the water flush was complete, the fouled membrane water flux was determined using the same settings as for CWF. Typically, the fouled membrane flux was about $31 \%$ of the initial clean membrane water flux (1,897 vs. 585 $\mathrm{kg} / \mathrm{m}^{2}$ per hour). Next, the MF system was heated with RO water to $70^{\circ} \mathrm{C}$. The sodium hydroxide solution was added to hot RO water in the feed tank $(1.5 \% \mathrm{wt} /$ vol). The solution was recirculated for 15 min with the permeate valve closed. Then, the system was drained, and again an alkaline solution was added to the system $\left(1.5 \% \mathrm{wt} / \mathrm{vol} ; 70^{\circ} \mathrm{C}\right)$. The permeate outlet valve was slowly opened, and the alkaline solution was recirculated for $30 \mathrm{~min}$. After the cleaning, the membrane system was slowly $\left(<10^{\circ} \mathrm{C} / \mathrm{min}\right)$ cooled to $50^{\circ} \mathrm{C}$ with the heat exchanger on the unit. The membrane was then flushed with room-temperature $\mathrm{RO}$ water until neutral $\mathrm{pH}$ was reached and the postrun CWF was determined. During the flux determination, the retentate outlet valve was closed, and the permeate outlet valve was fully open with only the feed pump on and the temperature maintained at approximately $20^{\circ} \mathrm{C}$. The postrun CWF was close to the prerun CWF $(1,878 \mathrm{~L} /$ $\mathrm{m}^{2}$ per hour). Then the MF flow system was heated 
to $70^{\circ} \mathrm{C}$ and a solution of nitric acid $(0.55 \% \mathrm{vol} / \mathrm{vol})$ was recirculated through the membrane at $70^{\circ} \mathrm{C}$ for 30 min with the permeate valve closed for the first $2 \mathrm{~min}$. After 30 min of the nitric acid solution recirculation, permeate and retentate outlet valves were closed and the pumps turned off. The membrane was stored in a $0.55 \%$ nitric acid solution.

\section{Cold MF}

The milk (thermized, pasteurized, and 1.4 MF) after cold storage was cold microfiltered (average temperature during processing was $6^{\circ} \mathrm{C}$ ) using a benchtop crossflow pilot MF system (Pall Membralox XLAB 5, Pall Corp.) equipped with $0.1-\mu \mathrm{m}$ nominal pore diameter ceramic Membralox (ET1-070, $\alpha$-alumina, Pall Corp.) membrane. Each milk was processed on a separate day. The milk $(\sim 1.2 \mathrm{~L})$ was recirculated for $5 \mathrm{~min}$ in the system with the permeate valve closed; then, the permeate valve was slowly opened and the permeate was collected. The flux $\left(\mathrm{kg} / \mathrm{m}^{2}\right.$ per hour) was determined every 20 min and was calculated based on the weight of permeate collected in $20 \mathrm{~min}$ and the total membrane surface area. At the end of the MF run, all retentate (the retentate was drained from the system by opening the 2 valves) and all permeate collected from the processing run were mixed and each was sampled. The average total time of milk processing was about $285 \mathrm{~min}$. The process was carried out to reach $1.5 \times$ concentration factor. The cleaning before and after the process was done as described for MF of milk for bacteria removal.

\section{Chemical and Instrumental Analyses}

The samples of skim milk, permeate, and retentate were analyzed using a MilkoScan FT2 (Foss, Hillerød, Denmark) for fat, lactose (anhydrous lactose), true protein content, and density. The $\mathrm{pH}$ of the starting and final MF products was monitored using a $\mathrm{pH}$ meter (SevenMulti; Mettler Toledo, Greifensee, Switzerland) equipped with an electrode LE427 (Mettler Toledo).

The samples of raw and skim milk (1.4 MF, thermized, and pasteurized) before processing, final retentates, and permeates were analyzed for TS, TN, noncasein nitrogen (NCN), and NPN content using forced-air oven drying (AOAC International, 2007; method 990.20; 33.2.44), Kjeldahl method (AOAC International, 2007; method 991.20; 33.2.11), Kjeldahl method (AOAC International, 2007; method 998.05; 33.2.64) with modifications according to Wojciechowski and Barbano (2015), and Kjeldahl method (AOAC International, 2007; method 991.21; 33.2.12), respectively. True protein was calculated by subtracting NPN from $\mathrm{TN}$ and then multiplying by 6.38 , casein was calculated by subtracting NCN from TN and multiplying by 6.38 , and serum protein (SP) content was calculated by subtracting NPN from NCN and multiplying by 6.38. All samples were analyzed fresh.

The viscosity of skim milk subjected to different temperature treatment-1.4 MF for bacteria removal (no heat treatment), thermization, and pasteurizationand the retentates produced from those milks were determined using rotational rheometer (RheolabQC, Anton Paar, Graz, Austria) at a shear rate of $100 \mathrm{~s}^{-1}$ and a temperature of $6^{\circ} \mathrm{C}$.

\section{SDS-PAGE Electrophoresis}

To determine the relative proportion of $\beta$-casein to $\alpha$-casein and passage of serum proteins (especially $\beta$-LG and $\alpha$-LA) through the membrane from skim milk (1.4 MF, thermized, and pasteurized), a $12 \%$ polyacrylamide gel (Bio-Rad Laboratories Inc., Hercules, CA) was used. The fresh samples $(0.1 \mathrm{~mL}$ for milk and retentate and $0.3 \mathrm{~mL}$ for permeate) were diluted with sample buffer (0.9 or $0.7 \mathrm{~mL}$, respectively) that contained $10 \mathrm{mM}$ Tris- $\mathrm{HCl}(\mathrm{pH} 6.8), 1.0 \%$ SDS, $20 \%$ glycerol, $0.02 \%$ bromophenol blue tracking dye, and 50 $\mathrm{m} M$ dithiothreitol and were stored frozen. Before the analysis, the samples were thawed at room temperature. The diluted samples in plastic vials (Eppendorf microtubes, 3810X; Merck, Darmstadt, Germany) were heated to $100^{\circ} \mathrm{C}$ in a steam chamber and held for $3 \mathrm{~min}$. The skim milk, permeates, and retentates were loaded (9, 20, and $7 \mu \mathrm{L}$, respectively) onto an SDS-PAGE gel. Each sample was replicated 3 times on a gel. The procedure of Verdi et al. (1987) was used for running, staining, and destaining the gels. The gels were scanned with a USB GS 800 Densitometer using Quantity One 1-D Analysis Software (Bio-Rad Laboratories Inc.) to obtain relative protein proportions within each sample.

\section{Transmission and Removal of $\beta$-Casein}

The transmission of SP and $\beta$-casein during the process of cold MF was calculated according to the formula (Le Berre and Daufin, 1994)

$$
\text { Transmission }=100 \times\left(\mathrm{C}_{\mathrm{p}} / \mathrm{C}_{\mathrm{r}}\right),
$$

where $\mathrm{C}_{\mathrm{p}}$ and $\mathrm{C}_{\mathrm{r}}$ are the concentration of the species in the permeate and retentate, respectively. The content of $\beta$-casein in the retentate was calculated based on casein content (Kjeldahl method) and $\beta$-casein as a percentage of total casein (sum of $\alpha$-casein, $\beta$-casein, and $\kappa$-casein relative content; $\boldsymbol{\beta}-\mathbf{C N} \% \mathbf{C N}$ ) determined based on SDS-PAGE electrophoresis. It was assumed that the casein in the permeate is $\beta$-casein. 
The efficiency of removal of $\beta$-casein from skim milk was measured in a mass-balance experiment by measuring the weight of skim milk to be processed and the concentration of casein in the skim milk. The total weight of casein present in the skim milk was calculated. Based on the results from SDS-PAGE electrophoresis, $\beta$-casein content (\%) in milk was calculated $(\beta-\mathrm{CN} \% \mathrm{CN})$. Among the caseins present in milk, 37.04, 37.94, and $36.08 \%$ was $\beta$-casein for thermized, pasteurized, and 1.4 MF skim milk, respectively. The $\beta$-casein removed from the skim milk was calculated by multiplying the weight of permeate removed by the MF process by the concentration of casein in the permeate. It was assumed, based on SDS-PAGE electrophoresis results, that the casein present in the permeate was only $\beta$-casein. From those values the total weight of $\beta$-casein removed was calculated. The weight of $\beta$-casein removed divided by the weight of $\beta$-casein at the beginning multiplied by 100 is the percentage of $\beta$-casein reduction achieved by the MF process.

\section{RESULTS AND DISCUSSION}

\section{Composition}

Feed. The composition of the milks is given in Table 1. Higher NCN content in 1.4 MF milk resulted in lower casein content in comparison with thermized and pasteurized milks. Consequently, casein as a percentage of true protein $(\mathbf{C N \%}$ TP $)$ was significantly $(P<0.05)$ lower for 1.4 MF milk than for thermized and pasteurized milks. A difference $(P<0.05)$ was found in SP content when comparing 1.4 MF milk with thermized and pasteurized milks. The mean $(\mathrm{n}=4)$ composition of the retentate produced from skim milk using MF membranes with pore size diameter of $1.4 \mu \mathrm{m}$ (MF for bacteria removal) was $0.22,3.83$, and 4.66 for fat, protein, and lactose, respectively, as measured using a MilkoScan (model FT2; Foss). The process of MF for bacteria removal was carried out at the temperature of $49.2^{\circ} \mathrm{C}$ and the flux of $278.46 \mathrm{~kg} / \mathrm{m}^{2}$ per hour during 148 min. The flux at the end of the process was $20 \%$ of the initial process flux. The average decline in processing flux was $77.72 \%$. In general, the process was carried out to achieve as small a volume of the retentate as possible or until the satisfactory flux was maintained. The retentate as a percentage of the feed was $10.75 \%$. There was a loss of feed material (4.53\%) during the process, probably as a result of milk evaporation and partial hold-up of the milk in the equipment. In industrial applications it is possible to reduce the retentate volume up to $0.5 \%$ of the original milk volume (Kumar et al., 2013). The lower casein content in 1.4 MF milk resulted from the casein retention in the retentate after $1.4-\mu \mathrm{m}$
MF (Table 1). No difference $(P>0.05)$ in CN\%TP was detected between thermized and pasteurized milk (Table 1). Thermal processing of milk may result in denaturation of milk SP and formation of intermolecular disulfide bonds between $\beta$-LG and $\kappa$-casein (Harland et al., 1952). Two variants of heat treatment were applied during this study: thermization $\left(65^{\circ} \mathrm{C}, 20 \mathrm{~s}\right)$ and pasteurization $\left(72^{\circ} \mathrm{C}, 15 \mathrm{~s}\right)$. Pasteurization at $72^{\circ} \mathrm{C}$ for $15 \mathrm{~s}$ is the most common heat treatment applied in cheese making. Measurement of CN\%TP and the difference in this value before and after pasteurization is an indication of the degree of denaturation of SP. Ma et al. (2000) showed that the increase in CN\% TP in commercial fluid milk pasteurized at $74^{\circ} \mathrm{C}$ for $34 \mathrm{~s}$ was about $3 \%$, which suggests that the heat treatment conditions used in our study produced minimal heat denaturation of SP. Thus, CN\%TP is a rather poor indicator of the changes that occur in casein micelles during chilled storage of milk. However, the binding of SP to casein that resulted from excessive heat treatment could cause the reduction in the efficiency of MF process as lower SP removal can be observed.

The $\mathrm{pH}$ of the starting material, retentates, and permeates is presented in Table 2. No significant differences $(P>0.05)$ between different treatments were detected. However, the $\mathrm{pH}$ for retentates and permeates increased $(P<0.05$; data not shown $)$ in comparison with the $\mathrm{pH}$ of the starting material.

Retentate. Table 3 presents the composition of the retentates produced from 1.4 MF, thermized, and pasteurized milks using a cold MF system equipped with a $0.1-\mu \mathrm{m}$ membrane. Lower casein content in the retentate from 1.4 MF milk was the result of the lower casein content in the feed that this retentate was produced from; however, it could also suggest that higher casein passage through the membrane occurred. During the MF process for bacteria removal, the casein micelles likely were partially rejected by the membrane if they were clustered to or associated with the fat. Changes in the size distribution of casein micelles and fat globules can affect the membrane performance. Colloids with a size close to the cut-off value of the membrane get caught and obstruct the passage of smaller components. This puts an extra load on the still-unblocked membrane area and increases the danger of further blocking the membrane pores (APV Membrane Filtration, 2012). No difference $(P>0.05)$ was detected in mean composition between the retentates produced from thermized and pasteurized skim milks.

Permeate. Small but detectable $(P<0.05)$ differences in casein content between permeate produced from pasteurized and permeate from 1.4 MF and thermized milk (Table 4) were detected. Such results suggest that the passage of casein is hindered when pasteurized milk 
Table 2. Mean $(\mathrm{n}=4) \mathrm{pH}$ values $\left(20^{\circ} \mathrm{C}\right)$ of the starting material and final retentate and permeate of skim milk subjected to different temperature treatments [microfiltration using 1.4- $\mu \mathrm{m}$ membranes at $50^{\circ} \mathrm{C}$ for bacteria removal (no heat treatment, 1.4 MF), thermization, and pasteurization]

\begin{tabular}{lccc}
\hline Milk & Feed & Retentate & Permeate \\
\hline $1.4 \mathrm{MF}$ & $6.75^{\mathrm{a}}$ & $6.84^{\mathrm{a}}$ & $6.87^{\mathrm{a}}$ \\
Thermized & $6.75^{\mathrm{a}}$ & $6.86^{\mathrm{a}}$ & $6.86^{\mathrm{a}}$ \\
Pasteurized & $6.76^{\mathrm{a}}$ & $6.87^{\mathrm{a}}$ & $6.91^{\mathrm{a}}$ \\
\hline
\end{tabular}

${ }^{a}$ Means within a column with different superscripts are different $(P$ $<0.05)$.

is subjected to cold MF using a 0.1- $\mu \mathrm{m}$ membrane. However, at this level of casein concentration the accuracy of the Kjeldahl method should be taken into account. It is interesting to note that the SP content in the permeates was relatively low $(0.11-0.12 \%$; Table 4). For instance, $0.51 \%$ of SP was reported by Zulewska and Barbano (2014) when the process of MF was carried out at $50^{\circ} \mathrm{C}$ with $3 \times$ concentration factor $(\mathbf{C F})$ using graded permeability MF membranes. In contrast, the casein concentration observed in the permeate collected at $6^{\circ} \mathrm{C}$ was similar to that reported for the process operated at $50^{\circ} \mathrm{C}(0.03 \%$; Zulewska and Barbano, 2014). Thus, it appears that the casein in the permeate was a higher percentage of the true protein in the permeates produced using 0.1- $\mu \mathrm{m}$ MF membranes resulting from smaller SP passage. However, the permeates produced from skim milk with the MF process carried out at $50^{\circ} \mathrm{C}$ using ceramic uniform transmembrane pressure, ceramic graded permeability, and polymeric spiral wound membranes showed the presence of other casein fractions (i.e., $\alpha$-casein; Zulewska et al., 2009).

Processing. No difference $(P>0.05)$ in average flux $\left(\mathrm{kg} / \mathrm{m}^{2}\right.$ per hour) during processing of $1.4 \mathrm{MF}$, thermized, and pasteurized skim milk was detected (Table $5)$. The initial flux was $17.94,18.33$, and $18.84 \mathrm{~kg} /$ $\mathrm{m}^{2}$ per hour for $1.4 \mathrm{MF}$, thermized, and pasteurized skim milk, respectively (Figure 2). For comparison, the average flux during processing of skim milk with ceramic uniform transmembrane pressure and graded permeability membranes was 54.08 and $71.79 \mathrm{~kg} / \mathrm{m}^{2}$ per hour, respectively, when the process was carried out at $3 \times \mathrm{CF}$ and $50^{\circ} \mathrm{C}$ (Zulewska et al., 2009). Interestingly, for the process described above (Zulewska et al., 2009), the flux for spiral wound polymeric membranes was $16.21 \mathrm{~kg} / \mathrm{m}^{2}$ per hour at $50^{\circ} \mathrm{C}$, which is similar to the results that were obtained for the current process. The higher linear velocity during ceramic membrane operation, usually 6 to $7 \mathrm{~m} / \mathrm{s}$ versus $0.19 \mathrm{~m} / \mathrm{s}$ for spiral wound membranes (Zulewska and Barbano, 2013), creates turbulent flow that minimizes fouling. In turn, Le Berre and Daufin (1994) achieved the permeation flux of $<45 \mathrm{~L} / \mathrm{m}^{2}$ per hour for the $\beta$-casein separation 
process using sodium caseinate with Carbosep ceramic membranes (Tech-Sep, Miribel, France) at $4^{\circ} \mathrm{C}$ when the process was carried out at a small transmembrane pressure gradient of $<0.2 \mathrm{MPa}$.

The flux during the process was very temperature dependent. The temperature increase resulted in higher flux as the viscosity of the feed solution decreased. The average temperature during processing was $5.88^{\circ} \mathrm{C}$ $\left(5.62,5.93\right.$, and $6.09^{\circ} \mathrm{C}$ for $1.4 \mathrm{MF}$, thermized, and pasteurized skim milk, respectively; Table 5). The initial temperature of each milk was equal to the temperature of milk during storage and was $2^{\circ} \mathrm{C}$. The water circulating in the water jacket of the feed tank had a temperature of $2^{\circ} \mathrm{C}$. Additionally, the milk was cooled by the chilled water circulating inside a helical glass element inserted in the tank (Figure 1). The chilling system was not efficient enough to keep the temperature during the processing below $4^{\circ} \mathrm{C}$. The first measurement of the temperature and flux was done after $25 \mathrm{~min}(5$ min recirculation and 20 min permeate collection) of processing, and already at this time the average temperature was higher than $5^{\circ} \mathrm{C}$. Presumably, the linear velocity of the retentate $(6 \mathrm{~m} / \mathrm{s})$ caused by the work of the pump produced an amount of heat to increase the temperature of the feed material remaining in the feed tank. No difference in flux decline (\%) during processing of 1.4 MF, thermized, and pasteurized skim milk was detected (average decline $=10.49 \%$; Table $5)$. This would indicate that the resistance to passage did not increase during processing. The fouling layer, once it built up at the beginning of the process, did not increase substantially in the subsequent minutes of processing. This suggests that the maximum fouling did occur at the beginning of the process as a result of fouling layer formation on the membrane surface once the membrane was exposed to skim milk flow. The difference in TP content between 1.4 MF milk and thermized and pasteurized milks, with 1.4 MF milk having the lowest TP content (Table 1), did not affect the flux decrease at this temperature of processing.

Concentration factor was calculated either based on the weight of feed and retentate or based on the weight of retentate and permeate (Table 5). No difference in $\mathrm{CF}$ when processing 1.4 MF, thermized, and pasteurized milk was detected $(P>0.05)$. An average $\mathrm{CF}$ was 1.56 for all treatments when taking into account the weight of retentate and permeate (Table 5).

The degree of fouling was measured based on water permeation fluxes before and after processing skim milk. Fouled water flux measured directly after processing of skim milk corresponded to $25 \%$ of the initial CWF before processing (Table 6). The flux decline was 74.20 , 77.84 , and $74.42 \%$ when processing $1.4 \mathrm{MF}$, thermized, and pasteurized skim milk (Table 6), respectively, with 
Table 4. Mean $(n=4)$ composition $^{1}$ ( $\%$ by weight) of the permeates produced with $1.5 \times$ batch process at chilled temperature using $0.1-\mu m$ ceramic microfiltration membrane from skim milk subjected to different temperature treatments [microfiltration using 1.4- $\mu$ m membranes at $50^{\circ} \mathrm{C}$ for bacteria removal (no heat treatment, $1.4 \mathrm{MF}$ ), thermization, and pasteurization]

\begin{tabular}{|c|c|c|c|c|c|c|c|}
\hline Milk & TS & $\mathrm{CP}$ & $\mathrm{NCN}$ & $\mathrm{NPN}$ & $\mathrm{TP}$ & Casein & Serum proteins \\
\hline Thermized & $5.40^{\mathrm{a}} \pm 0.27$ & $0.32^{\mathrm{a}} \pm 0.01$ & $0.29^{\mathrm{a}} \pm 0.01$ & $0.17^{\mathrm{a}} \pm 0.01$ & $0.14^{\mathrm{a}} \pm 0.01$ & $0.03^{\mathrm{a}} \pm 0.003$ & $0.11^{\mathrm{a}} \pm 0.01$ \\
\hline
\end{tabular}

${ }_{\mathrm{a}, \mathrm{b}}$ Means within a column with different superscripts are different $(P<0.05)$.

${ }^{1} \mathrm{CP}$ calculated as total $\mathrm{N} \times 6.38 . \mathrm{NCN}=$ noncasein nitrogen $\times 6.38 . \mathrm{NPN}=$ nonprotein nitrogen $\times 6.38$. True protein $(\mathrm{TP})$ calculated as $\mathrm{CP}$ - NPN. Casein calculated as CP - NCN. CN\%TP = casein as a percentage of true protein. Serum proteins calculated as TP - casein.

a 0.1- $\mu \mathrm{m}$ MF membrane at chilled temperature, and no difference $(P>0.05)$ was detected between different treatments.

Maubois and Ollivier (1992) recommended high recirculation velocity of the retentate (at least $6 \mathrm{~m} / \mathrm{s}$ ) for a satisfactory process of $\beta$-casein separation with cold MF. In the current experiment we ran the process under the conditions recommended by the manufacturer of the membranes. The linear velocity of $6 \mathrm{~m} / \mathrm{s}$ was applied for all treatments. The crossflow velocity affects the wall shear stress ( $\boldsymbol{\tau}_{\mathrm{w}}$; Samuelsson et al., 1997). The wall shear stress $\left(\tau_{\mathrm{w}}=f \rho v^{2} / 2\right)$ was calculated from crossflow velocity $(v)$ using Blasius's law (friction factor, $f=0.0792$ Reynold's number, $\mathrm{Re}^{-0.25}$; Samuelsson et al., 1997). For measured density $(\rho)$ and viscosity of the retentates (Table 7) and inner diameter of the tube $\left(0.007 \mathrm{~m}\right.$ ), the wall shear stress was $134.19 \mathrm{~N} \mathrm{~m}^{-2}$ (on average).

Permeation flux and tangential flow velocity, through the wall shear stress, are the major parameters responsible for a proper membrane separation process (Le Berre and Daufin, 1996). Several researchers recommend performing the MF process at flux less than the limiting flux conditions. The limiting flux represents the maximum stationary permeation flux that can be reached when increasing transmembrane pressure (Aimar and Field, 1992; Bacchin, 2004) and depends on crossflow velocity, temperature, feed suspension properties, and geometry of the module (Samuelsson et al., 1997). Samuelsson et al. (1997) investigated 4 models for rejected solute back-transport mechanisms in crossflow MF to predict the limiting permeate flux for skim milk. Among the models discussed (i.e., Brownian diffusion model, shear-induced diffusion model, inertial lift model, and surface transport model) by Samuelsson et al. (1997), only the shear-induced diffusion model predicted values of the limiting flux close to their experimental data. The researchers suggested that at wall shear stresses of about $100 \mathrm{~N} \mathrm{~m}^{-2}$, the shear-induced diffusion is the dominant mechanism for back transport. In our experiment, the values of the limiting flux calculated with the shear-induced diffusion model were very close to the actual flux during the processing. However, the flux decline of only $10.5 \%$ (average value for processing 3 different kinds of milk; Table 5) was observed during the processing of skim milk subjected to different heat treatments. On the other hand, the water flux after processing corresponded to approximately $25 \%$ of the initial CWF (Table 6 ). This suggests that the maximum fouling did occur at the beginning of the process as a result of fouling layer formation on the membrane surface once the membrane was exposed to skim milk flow. The milk $(\sim 1.2 \mathrm{~L})$ at the start-up was recirculated for 5 min in the system with the permeate valve closed, and then the permeate valve was slowly opened and the permeate was collected. It is possible that a different procedure at the start-up (i.e., slow transition from water to milk) would bring better results in terms of the flux and membrane performance.

Unlike the limiting flux, the critical flux is a concept that describes the flux below which little or no deposition exists on the membrane surface and above which

Table 5. Mean $(\mathrm{n}=4)$ temperature, concentration factor $(\mathrm{CF})$, flux, and flux decline during cold microfiltration of skim milk subjected to different temperature treatments [microfiltration using $1.4-\mu \mathrm{m}$ membranes at $50^{\circ} \mathrm{C}$ for bacteria removal (no heat treatment, $1.4 \mathrm{MF}$ ), thermization, and pasteurization]

\begin{tabular}{lccccc}
\hline Milk & $\begin{array}{c}\text { Temperature } \\
\left({ }^{\circ} \mathrm{C}\right)\end{array}$ & $\begin{array}{c}\mathrm{CF}^{1} \text { based on feed } \\
\text { and retentate weights }\end{array}$ & $\begin{array}{c}\mathrm{CF}^{2} \text { based on retentate } \\
\text { and permeate weights }\end{array}$ & $\begin{array}{c}\text { Flux }\left(\mathrm{kg} / \mathrm{m}^{2}\right. \\
\text { per hour } \pm \mathrm{SD})\end{array}$ & $\begin{array}{c}\text { Flux decline at end } \\
\text { of processing }\end{array}$ \\
\hline $1.4 \mathrm{MF}$ & $5.62^{\mathrm{a}} \pm 1.10$ & $1.66^{\mathrm{a}} \pm 0.08$ & $1.56^{\mathrm{a}} \pm 0.05$ & $16.5^{\mathrm{a}} \pm 1.5$ & $9.41^{\mathrm{a}}$ \\
Thermized & $5.93^{\mathrm{a}} \pm 0.95$ & $1.64^{\mathrm{a}} \pm 0.07$ & $1.56^{\mathrm{a}} \pm 0.04$ & $17.1^{\mathrm{a}} \pm 1.4$ & $11.95^{\mathrm{a}}$ \\
Pasteurized & $5.09^{\mathrm{a}} \pm 1.05$ & $1.63^{\mathrm{a}} \pm 0.03$ & $1.56^{\mathrm{a}} \pm 0.02$ & $17.2^{\mathrm{a}} \pm 1.3$ & $10.11^{\mathrm{a}}$ \\
\hline
\end{tabular}

${ }^{\mathrm{a}}$ Means in the same column sharing a common superscript are not different $(P<0.05)$.

${ }^{1}$ Calculated as feed weight/retentate weight.

${ }^{2}$ Calculated as (retentate weight + permeate weight)/retentate weight. 
Table 6. Initial clean water flux (CWF), fouled water flux (FWF), and postrun CWF in skim milk subjected to different temperature treatments [microfiltration using $1.4-\mu \mathrm{m}$ membranes at $50^{\circ} \mathrm{C}$ for bacteria removal (no heat treatment, 1.4 MF), thermization, and pasteurization]

\begin{tabular}{lcccc}
\hline Milk & $\begin{array}{c}\text { Initial CWF } \\
\left(\mathrm{kg} / \mathrm{m}^{2} \text { per hour }\right)\end{array}$ & $\begin{array}{c}\text { FWF } \\
\left(\mathrm{kg} / \mathrm{m}^{2} \text { per hour }\right)\end{array}$ & $\begin{array}{c}\text { Flux decline } \\
(\%)\end{array}$ & $\begin{array}{c}\text { Postrun CWF } \\
\left(\mathrm{kg} / \mathrm{m}^{2} \text { per hour }\right)\end{array}$ \\
\hline $1.4 \mathrm{MF}$ & $840.40^{\mathrm{a}}$ & $200.03^{\mathrm{a}}$ & $74.20^{\mathrm{a}}$ & $1,075.06^{\mathrm{a}}$ \\
Thermized & $915.06^{\mathrm{a}}$ & $208.72^{\mathrm{a}}$ & $77.84^{\mathrm{a}}$ & $1,026.76^{\mathrm{a}}$ \\
Pasteurized & $983.16^{\mathrm{a}}$ & $247.16^{\mathrm{a}}$ & $74.42^{\mathrm{a}}$ & $1,156.24^{\mathrm{a}}$ \\
\hline
\end{tabular}

${ }^{a}$ Means within a column with different superscripts are different $(P<0.05)$.

${ }^{1}$ Calculated as [(initial CWF - FWF $) /$ initial CWF $] \times 100$.

there is a sharp increase in fouling (Bacchin et al., 1995; Howell, 1995; Gésan-Guiziou et al., 1999; Bacchin, 2004). Bacchin (2004) suggested that the critical flux is equal to two-thirds of the limiting flux. In the current experiment, the critical flux was calculated from the limiting flux determined according to the model proposed by Samuelsson et al. (1997) and was almost 25 $\mathrm{kg} / \mathrm{m}^{2}$ per hour. This suggests that we have operated at the flux below the limiting and critical flux values (Tables 6 and 7).

The value of the critical flux is also influenced by $\tau_{w}$. The ratio of $\mathrm{J} / \tau_{w}$, where $\mathrm{J}=$ flux, has been used to evaluate membrane filtration performance regarding fouling and selectivity (Grandison et al., 2000). The ratio defines the balance of particle deposition rate (relating to flux) and particle removal rate (relating to shear stress; Gésan-Guiziou et al., 2000). To achieve satisfactory MF performance (i.e., minimum fouling at high protein transmission), it is recommended to operate under conditions in which the ratio of flux to wall shear stress is lower than a critical value (Grandison et al., 2000). This concept is similar to the critical flux concept but also takes into account the effect of $\tau_{w}$ (Grandison et al., 2000). Le Berre and Daufin (1996) assessed the critical value of this ratio close to 1.0 $\mathrm{L} \cdot \mathrm{h}^{-1} \cdot \mathrm{m}^{-2} \cdot \mathrm{Pa}^{-1}$. In our experiment, the ratio of flux to wall shear stress was well below the critical value $(0.12$,
0.13 , and $0.13 \mathrm{~kg} \cdot \mathrm{h}^{-1} \cdot \mathrm{m}^{-2} \cdot \mathrm{Pa}^{-1}$ for $1.4 \mathrm{MF}$, thermized, and pasteurized skim milk, respectively). Low values of this ratio indicate higher particle removal rate than particle deposition rate. Several researchers reported the value of this ratio to be in the range of 0.5 to 0.6 $\mathrm{kg} \cdot \mathrm{h}^{-1} \cdot \mathrm{m}^{-2} \cdot \mathrm{Pa}^{-1}$ when the process of MF was carried out at the temperature of $50^{\circ} \mathrm{C}$ (Gésan-Guiziou et al., 2000; Zulewska and Barbano, 2014).

The values of the major parameters (permeation flux and tangential flow velocity, through the wall shear stress) responsible for a proper membrane separation process were considerably lower than the critical values. However, the performance of the MF membranes for protein separation at refrigerated temperatures is highly affected by the properties of the feed material, especially the viscosity of the feed material. By adding water or UF permeate to the feed material we could change the properties of the feed, in particular the viscosity. On the other hand, Pierre and Brulé (1981) suggested that an optimum of $\beta$-casein solubilization from casein micelles in milk occurs at a protein concentration of $30 \mathrm{~g} / \mathrm{L}$ of total milk proteins.

SP and $\beta$-Casein Transmission. The results of SDS-PAGE gels analysis (Figures 3 and 4) are presented as a relative percentages of $\beta$-casein to $\alpha_{S}$-casein and $\beta$-casein as a percentage of casein $(\beta-\mathrm{CN} \% \mathrm{CN})$ in Table 8 for skim milk subjected to different temperature

Table 7. Mean $(\mathrm{n}=4)$ viscosity $(\mathrm{Pa} \cdot \mathrm{s})$ and density at $20^{\circ} \mathrm{C}\left(\mathrm{g} / \mathrm{cm}^{3}\right)$ of skim milk subjected to different temperature treatments $[$ microfiltration using 1.4- $\mathrm{mm}$ membranes at $50^{\circ} \mathrm{C}$ for bacteria removal (no heat treatment, $1.4 \mathrm{MF}$ ), thermization, and pasteurization] and retentates produced from those milks using cold microfiltration process at $1.5 \times$ and performance characteristics (wall shear stress, $\mathrm{J} / \tau_{\mathrm{w}}$, limiting and critical flux) when processing each milk

\begin{tabular}{|c|c|c|c|c|c|c|c|}
\hline Milk & $\begin{array}{l}\text { Viscosity } \\
(\mathrm{Pa} \cdot \mathrm{s})\end{array}$ & $\begin{array}{l}\text { Density } \\
\left(\mathrm{kg} / \mathrm{m}^{3}\right)\end{array}$ & $\begin{array}{l}\text { Wall shear } \\
\text { stress }(\mathrm{Pa})\end{array}$ & $\left(\mathrm{kg} \cdot \mathrm{h}^{-1} \cdot \mathrm{m}^{-2} \cdot \mathrm{Pa}^{-1}\right)$ & \multicolumn{2}{|c|}{ Limiting flux } & $\begin{array}{l}\text { Critical } \\
\text { flux }^{4}\end{array}$ \\
\hline Thermized & $0.0029 \pm 0.0003$ & $1.0365 \pm 0.0016$ & 133.49 & 0.13 & 37.53 & 16.88 & 25.02 \\
\hline Pasteurized & $0.0031 \pm 0.0004$ & $1.0367 \pm 0.0014$ & 135.73 & 0.13 & 35.11 & 16.06 & 23.41 \\
\hline
\end{tabular}

${ }^{1} \mathrm{~J}=$ flux; $\tau_{\mathrm{w}}=$ wall shear stress

${ }^{2}$ According to the equation Reynold's number $(\mathrm{Re}) \times 6.94 \times 10^{-10} \mathrm{~m} / \mathrm{s}$ (Samuelsson et al., 1997).

${ }^{3}$ Samuelsson et al. (1997).

${ }^{4}$ Corresponds to two-thirds of the limiting flux calculated according to the equation proposed by Samuelsson et al. (1997). 


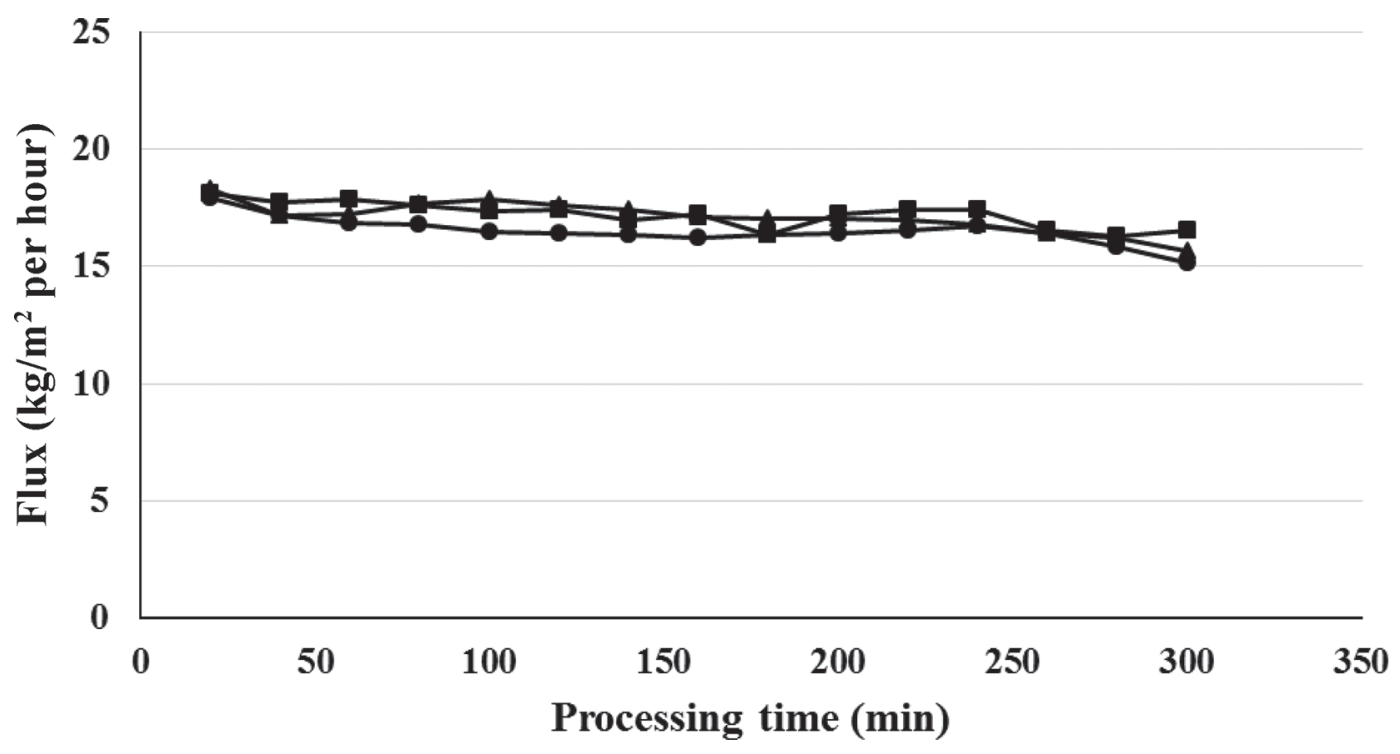

Figure 2. Mean $(\mathrm{n}=4)$ flux of a $0.1-\mu$ m ceramic microfiltration $(\mathrm{MF})$ membrane during processing of skim milk microfiltered using 1.4- $\mu \mathrm{m}$ membranes at $50^{\circ} \mathrm{C}$ for bacteria removal $\left(1.4 \mathrm{MF}\right.$ skim milk; $\bullet$ ), thermized skim milk $(\mathbf{\Delta})$, and pasteurized skim milk $(\boldsymbol{\square})$ at $6{ }^{\circ} \mathrm{C}$.

treatments and retentates produced from those milks. The passage of $\beta$-casein was monitored as a change of $\beta$-casein: $\alpha_{S}$-casein ratio between milk and the retentate produced from that milk. The significant difference in this ratio was detected $(P<0.05)$ between $1.4 \mathrm{MF}$ and thermized skim milks and the subsequent retentates. These findings are in agreement with the results of Kjeldahl analysis for casein content of the permeates. Small but detectable differences $(P<0.05)$ were found in casein content between different permeates, with the permeates produced from 1.4 MF and thermized skim milk having higher casein content compared with permeate from pasteurized skim milk (Table 4). The analysis of SDS-PAGE gels demonstrated that there were no visible bands of other casein fractions (i.e., $\alpha_{S^{-}}$ casein or k-casein) in the permeates (Figure 4). That is why we concluded that the only casein fraction present in the permeate is $\beta$-casein. During one of the replicates (the data from that replicate were not included in calculation of the averages), there was a temperature increase of up to $12^{\circ} \mathrm{C}$ for $1.4 \mathrm{MF}$ skim milk, which caused the passage of $\alpha_{\mathrm{S}}$-casein (visible band at SDSPAGE electropherogram). The only difference $(P<$ $0.05)$ in $\beta$-casein as a percentage of casein was detected between thermized milk and the subsequent retentate (37.19 vs. $35.00 \%$, respectively; Table 8 ). No difference $(P>0.05)$ was detected in $\beta-\mathrm{CN} \% \mathrm{CN}$ for $1.4 \mathrm{MF}$ skim milk and pasteurized milk and their retentates.

Very low values of the transmission were observed during the cold MF process. The transmission of $\beta$-casein was the highest $(P<0.05)$ for $1.4 \mathrm{MF}$ and thermized skim milk (2.17 and $2.27 \%$, respectively; Table 9 ). No difference $(P>0.05)$ was detected in CN\%TP (Table 1) between thermized and pasteurized milk used in this study, which may suggest that other factors play a role in dissociation of $\beta$-casein from the casein micelles at low temperature (i.e., mineral balance). Nonetheless, it is not clear whether the difference in $\beta$-casein transmission between 1.4 MF, thermized, and pasteurized milk results from the effect of heat treatment conditions on $\beta$-casein dissociation from the casein micelles or on passage of $\beta$-casein through the membrane.

One could expect that the $\beta$-casein transmission during cold MF of 1.4 MF skim milk will have the highest values. In the current experiment, there was no difference in transmission and removal of $\beta$-casein compared with 1.4 MF and thermized skim milk. Bowen and Gan (1991) showed that small changes occurred in the secondary structure of the protein when it was subjected to shear by stirring or passage through a membrane.

The transmission of SP was also very low compared with the data available in the literature for this process. The average SP transmission was $13.15 \%$, and no differences $(P>0.05)$ were detected among different heat treatments of the skim milk (Table 9 ). This corresponds with the SP content in the permeates that was earlier reported (Table 4 ).

The $\beta$-casein fractionation method is a key factor affecting the yield and purity of the obtained fractions. Creamer et al. (1977) used ultracentrifugation and gel filtration chromatography to separate micellar and serum caseins from milks. Huppertz et al. (2006) also developed a process to isolate $\beta$-casein from rennet-coagulated skim milk using centrifugation. Such methods 
offer high-purity product (i.e., $\sim 90 \%$ in relation to the total protein material in the first method).

The calculations of transmission and removal of $\beta$-casein were based on $\beta$-casein content in the permeate. The permeate content of $\beta$-casein is in turn affected by the degree of fouling. Generally, the proteins present in the feed solution subjected to the MF process can participate in 1 or more of the following membrane fouling phenomena: adsorption, deposition, and concentration polarization (Belfort et al., 1994). These interactions can cause pore constriction (narrowing), pore blockage (plugging), and gel or cake layer formation. When a diameter of a protein is much smaller than the diameter of a membrane pore, then the protein flows into the pore channel and deposits on the pore walls, and as a result the pore radius becomes narrowed (Belfort et al., 1994). Proteins with a diameter similar to the diameter of the pores are responsible for pore blocking, whereas when the proteins are bigger than most pores, they form deposit or cake on the upper surface of the membrane (Belfort et al., 1994). It is possible that $\beta$-caseins participate in one of the above-described phenomena.
If so, then the $\beta$-casein content in the permeate will be much less than the actual value removed due to the partial blockage of $\beta$-casein. It would be necessary to carry out additional research on fouling of the membrane during the cold MF process using an especially qualitative approach.

\section{CONCLUSIONS}

The study aimed to assess the possibility of application of cold MF in production of cheesemilk with reduced $\beta$-casein content. Although heat treatment had a small but significant effect on $\beta$-casein removal, the overall removal of $\beta$-casein was very low in all approaches. Thus, it seems that MF at a low temperature is not a viable process in its current form to reduce $\beta$-casein content of milk for cheese making. The yield of the process (i.e., $\beta$-casein removal) was less than $1 \%$, which makes the process unsuitable for commercial application. However, the proper selection of the membranes (i.e., smoothness of the membrane surface, diameter of the channels, geometry of the module) and

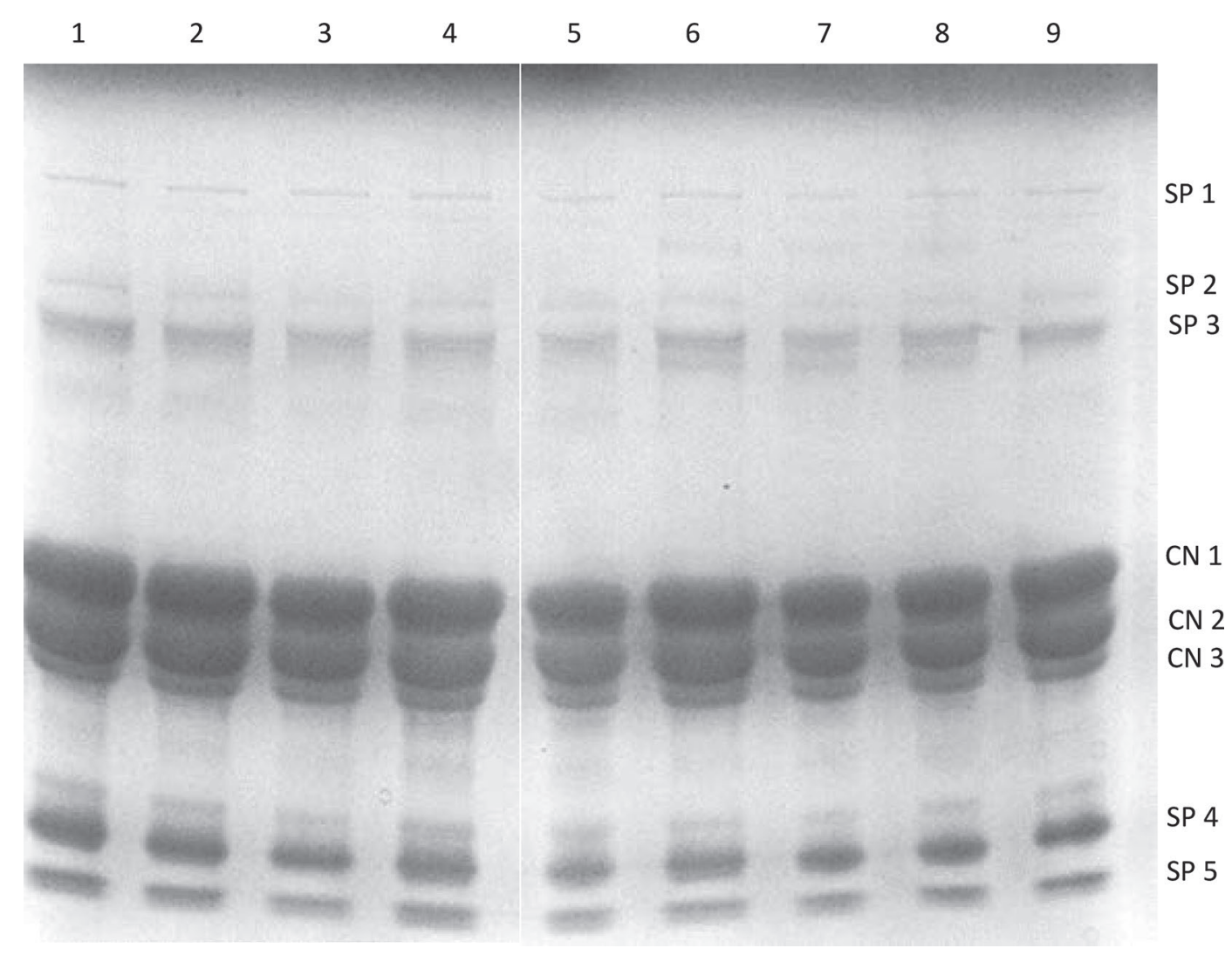

Figure 3. The proteins in skim milk (lane 9) and the microfiltration (MF) retentates produced by a 0.1- $\mu$ m ceramic MF membrane during processing of skim milk microfiltered using 1.4- $\mu \mathrm{m}$ membranes at $50^{\circ} \mathrm{C}$ for bacteria removal (1.4 MF; lanes 4 and 5), thermized skim milk (lanes 7, 8, and 9), and pasteurized skim milk (lanes 1, 2, and 3) at $6^{\circ} \mathrm{C}$. Bands in skim milk are identified on the gel: SP1, SP2, and SP3 = serum proteins; CN $1=\alpha_{\mathrm{S}^{-}}$casein (combination of $\alpha_{\mathrm{S}^{-}}$and $\alpha_{\mathrm{S}^{2}}$-casein); CN $2=\beta$-casein; CN $3=\kappa$-casein; SP $4=\beta$-LG; and SP $5=\alpha$-LA. 


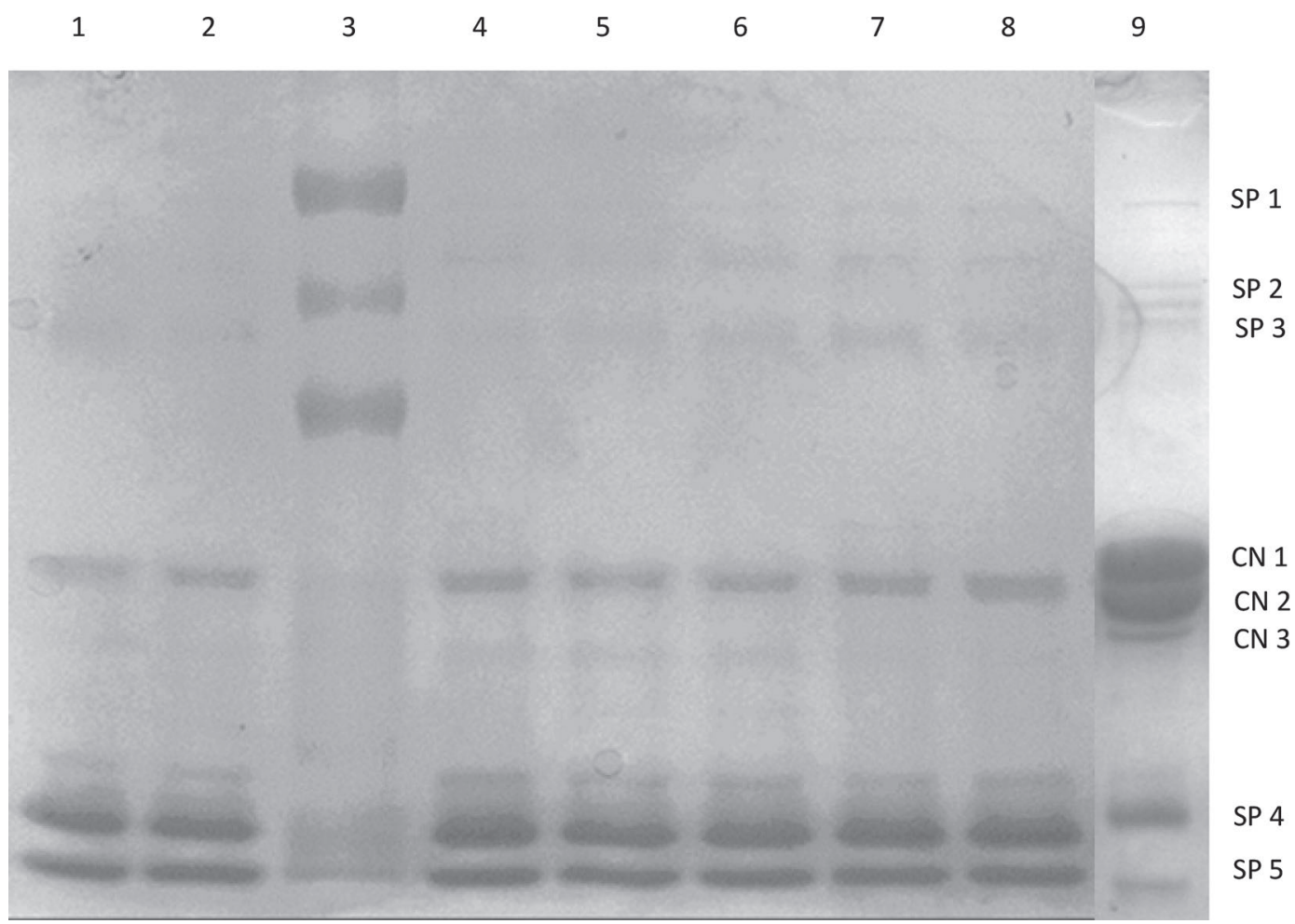

Figure 4. The proteins in skim milk (lane 9) and the microfiltration (MF) permeates produced by a 0.1- $\mu$ m ceramic MF membrane during processing of skim milk microfiltered using $1.4-\mu \mathrm{m}$ membranes at $50^{\circ} \mathrm{C}$ for bacteria removal $(1.4 \mathrm{MF}$; lanes 4,5 , and 6$)$, thermized skim milk (lanes 7 and 8), and pasteurized skim milk (lanes 1 and 2) at $6^{\circ} \mathrm{C}$. Lane 3 was the standard (Bio-Rad Laboratories, Hercules, CA). Bands in the permeate are identified on the gel: SP1, SP2, and SP3 = serum proteins; CN $1=\alpha_{\mathrm{S}^{-}}$-asein (combination of $\alpha_{\mathrm{S}^{-}}$and $\alpha_{\mathrm{S} 2}$-casein); CN $2=$ $\beta$-casein; CN $3=\kappa$-casein; SP $4=\beta$-LG; and SP $5=\alpha$-LA.

process parameters could possibly improve the removal of $\beta$-casein. The values of the major parameters (permeation flux and tangential flow velocity, through the wall shear stress) responsible for a proper membrane separation process were considerably lower than the critical values. This would suggest that there should be little or no deposition on the membrane surface. It

Table 8. Mean $(\mathrm{n}=4)$ ratio of $\beta$-casein to $\alpha_{\mathrm{S}^{-}} \mathrm{CN}(\beta-\mathrm{CN}: \alpha-\mathrm{CN})$ and $\beta$-casein as a percentage of casein $(\beta-\mathrm{CN} \% \mathrm{CN})$ for skim milk subjected to different temperature treatments [microfiltration using $1.4-\mu \mathrm{m}$ membranes at $50^{\circ} \mathrm{C}$ for bacteria removal (no heat treatment, 1.4 MF), thermization, and pasteurization] and retentates produced from those milks as analyzed by densitometry analysis of SDS-PAGE gels

\begin{tabular}{lcc}
\hline Treatment & $\beta-\mathrm{CN}: \alpha-\mathrm{CN}$ & $\beta-\mathrm{CN} \% \mathrm{CN}$ \\
\hline Skim milk & & \\
$1.4 \mathrm{MF}$ & $0.77^{\mathrm{a}} \pm 0.06$ & $37.07^{\mathrm{a}} \pm 2.26$ \\
Thermized & $0.79^{\mathrm{a}} \pm 0.07$ & $37.19^{\mathrm{a}} \pm 2.31$ \\
Pasteurized & $0.80^{\mathrm{a}} \pm 0.10$ & $37.34^{\mathrm{a}} \pm 3.19$ \\
Retentate from skim milk & & \\
1.4 MF & $0.72^{\mathrm{b}} \pm 0.04$ & $35.08^{\mathrm{a}} \pm 1.86$ \\
Thermized & $0.71^{\mathrm{b}} \pm 0.04$ & $35.00^{\mathrm{b}} \pm 1.45$ \\
Pasteurized & $0.75^{\mathrm{a}} \pm 0.03$ & $35.92^{\mathrm{a}} \pm 1.18$ \\
\hline
\end{tabular}

\footnotetext{
${ }^{\mathrm{a}, \mathrm{b}}$ Means within a column with different superscripts are different $(P$ $<0.05)$.
}

seems that the viscosity of the retentate has a great effect on the performance of the MF membranes for protein separation at refrigerated temperatures.

\section{ACKNOWLEDGMENTS}

This work was supported by the Polish National Science Center (Kraków, grant no. 2011/03/B/NZ9/05159). The authors thank Władysław Chojnowski, Maria Czerniewicz, and Bogusław Staniewski for scientific advice during project realization. The technical assistance of

Table 9. Transmission (Tr) of serum proteins (SP) and $\beta$-casein and removal of $\beta$-casein during cold microfiltration process using a 0.1 $\mu \mathrm{m}$ ceramic membrane at refrigerated temperature from skim milk subjected to different temperature treatments [microfiltration using $1.4-\mu \mathrm{m}$ membranes at $50^{\circ} \mathrm{C}$ for bacteria removal (no heat treatment, 1.4 MF), thermization, and pasteurization]

\begin{tabular}{lccc}
\hline Milk & SP $\operatorname{Tr}(\%)$ & $\beta-C N \operatorname{Tr}(\%)$ & $\beta$-CN removal $(\%)$ \\
\hline $1.4 \mathrm{MF}$ & $11.99^{\mathrm{a}}$ & $2.17^{\mathrm{a}}$ & $0.90 \pm 0.15$ \\
Thermized & $13.24^{\mathrm{a}}$ & $2.27^{\mathrm{a}}$ & $0.98 \pm 0.02$ \\
Pasteurized & $14.22^{\mathrm{a}}$ & $1.14^{\mathrm{b}}$ & $0.51 \pm 0.14$ \\
\hline
\end{tabular}

${ }_{\mathrm{a}, \mathrm{b}}$ Means within a column with different superscripts are different $(P$ $<0.05)$. 
Roman Łaszek, Waldemar Brandt, Krzysztof Jasiński, Maria Iglińska, and Justyna Ziajka (all from Department of Dairy Science and Quality Management, University of Warmia and Mazury in Olsztyn) was greatly appreciated. Use of names and names of ingredients and identification of specific models of equipment are for scientific clarity and do not constitute any endorsement of a product by the authors or the University of Warmia and Mazury.

\section{REFERENCES}

Aimar, P., and R. W. Field. 1992. Limiting flux in membrane separations: A model based on the viscosity dependency of the mass transfer coefficient. Chem. Eng. Sci. 47:579-586.

Ali, E. A., A. T. Andrews, and G. C. Cheeseman. 1980. Influence of storage of milk on casein distribution between the micellar and soluble phases and its relationship to cheese-making parameters. J. Dairy Res. 47:371-382.

AOAC International. 2007. Official Methods of Analysis. 18th ed. AOAC International, Gaithersburg, MD

APV Membrane Filtration. 2012. Removal of Bacteria and Spores from Milk, Using Membrane Filtration. SPX Corp., Silkeborg, Denmark.

Atamer, Z., A. E. Post, T. Schubert, A. Holder, R. M. Boom, and J. Hinrichs. 2017. Bovine $\beta$-casein: Isolation, properties and functionality. A review. Int. Dairy J. 66:115-125.

Bacchin, P. 2004. A possible link between critical and limiting flux for colloidal systems: Consideration of critical deposit formation along a membrane. J. Membr. Sci. 228:237-241.

Bacchin, P., P. Aimar, and V. Sanchez. 1995. Model for colloidal fouling of membranes. AIChE J. 41:368-376.

Belfort, G., R. H. Davis, and A. L. Zydney. 1994. The behavior of suspensions and macromolecular solutions in cross-flow microfiltration. J. Membr. Sci. 96:1-58.

Bowen, W. R., and Q. Gan. 1991. Properties of microfiltration membranes: Flux loss during constant pressure permeation of bovine serum albumin. Biotechnol. Bioeng. 38:688-696.

Creamer, L. K., G. P. Berry, and O. E. Mills. 1977. A study of the dissociation of $\beta$-casein from the bovine casein micelle at low temperature. N. Z. J. Dairy Sci. Technol. 12:58-66.

Davies, D. T., and A. J. R. Law. 1983. Variation in the protein composition of bovine casein micelles and serum casein in relation to micellar size and milk temperature. J. Dairy Res. 50:67-75.

Famelart, M. H., C. Hardy, and G. Brulé. 1989. Factors affecting the extraction of $\beta$-casein. Lait 69:47-57.

Farrell, H. M. Jr., R. Jimenez-Flores, G. T. Bleck, E. M. Brown, J. E. Butler, L. K. Creamer, C. L. Hicks, C. M. Hollar, K. F. Ng-KwaiHang, and H. E. Swaisgood. 2004. Nomenclature of the proteins of cows' milk-Sixth revision. J. Dairy Sci. 87:1641-1674.

Fox, P. F., and P. L. H. McSweeney. 1998. Milk proteins. Pages 180181 in Dairy Chemistry and Biochemistry. 1st ed. P. F. Fox and P. L. H. McSweeney, ed. Thomas Science, London, UK.

Gésan-Guiziou, G., E. Boyaval, and G. Daufin. 1999. Critical stability conditions in crossflow microfiltration of skimmed milk: Transition to irreversible deposition. J. Membr. Sci. 158:211-222.

Gésan-Guiziou, G., G. Daufin, and E. Boyaval. 2000. Critical stability conditions in crossflow microfiltration of skimmed milk: Impact on operating modes. Lait 80:129-140.

Grandison, A. S., W. Youravong, and M. J. Lewis. 2000. Hydrodynamic factors affecting flux and fouling during ultrafiltration of skimmed milk. Lait 80:165-174.
Harland, H. A., S. T. Coulter, and R. Jenness. 1952. The effect of the various steps in the manufacture on the extent of serum protein denaturation in nonfat dry milk solids. J. Dairy Sci. 35:363-368.

Howell, J. A. 1995. Sub-critical flux operation of microfiltration. J. Membr. Sci. 107:165-171.

Huppertz, T., J.-B. Hennebel, T. Considine, S. Ur-Rehman, A. L. Kelly, and P. F. Fox. 2006. A method for the large-scale isolation of $\beta$-casein. Food Chem. 99:45-50.

Kumar, P., N. Sharma, R. Ranjan, S. Kumar, Z. F. Bhat, and D. K. Jeong. 2013. Perspective of membrane technology in dairy industry: A review. Asian-australas. J. Anim. Sci. 26:1347-1358.

Le Berre, O., and G. Daufin. 1994. Fouling and selectivity of membranes during separation of $\beta$-casein. J. Membr. Sci. 88:263-270.

Le Berre, O., and G. Daufin. 1996. Skimmilk crossflow microfiltration performance versus permeation flux to wall shear stress ratio. J. Membr. Sci. 117:261-270.

Le Magnen, C., and J.-J. Maugas. 1995. Method for obtaining beta casein. US patent no. 5,397,577. Inventors: C. Le Magnen, J.-L. Maugas. Assignee: Eurial-Parc Club du Perray.

Ma, Y. C. Ryan, D. M. Barbano, D. M. Galton, M. A. Rudan, and K. J. Boor. 2000. Effects of somatic cell count on quality and shelf-life of pasteurized fluid milk. J. Dairy Sci. 83:264-274.

Maubois, J.-L., and G. Ollivier. 1992. Milk protein fractionation. IDF 9201:15-22.

Pierre, A., and G. Brulé. 1981. Mineral and protein equilibria between the colloidal and soluble phases of milk at low temperature. J. Dairy Res. 48:417-428.

Pouliot, M., Y. Pouliot, M. Britten, J.-L. Maubois, and J. Fauquant. 1994. Study of the dissociation of $\beta$-casein from native phosphocaseinate. Lait 74:325-332.

Samuelsson, G., I. H. Huisman, G. Tragardh, and M. Paulsson. 1997. Predicting limiting flux of skim milk in crossflow microfiltration. J. Membr. Sci. 129:277-281.

Terre, E., J.-L. Maubois, G. Brulé, and A. Pierre. 1987. Method for producing a material enriched in beta casein, apparatus for implementing such process, and application of the products obtained by this process as foodstuffs, food supplements or additives in food and pharmaceutical industry or in the production of peptides physiological activity. Patent no. FR2,592,769. Inventor: E. Terre, J.-L. Maubois, G. Brule, and A. Pierre. Current assignee: Institut National de la Recherche Agronomique INRA, Sigma-Tau Industrie Farmaceutiche Riunite SpA.

Van Hekken, D. L., and V. H. Holsinger. 2000. Use of cold microfiltration to produce unique $\beta$-casein enriched milk gels. Lait 80:69-76.

Verdi, R. J., D. M. Barbano, and M. E. Dellavalle. 1987. Variability in true protein, casein, nonprotein nitrogen, and proteolysis in high and low somatic cell count milks. J. Dairy Sci. 70:230-242.

Wojciechowski, K. L., and D. M. Barbano. 2015. Modification of the Kjeldahl noncasein nitrogen method to include bovine milk concentrates and milks from other species. J. Dairy Sci. 98:7510-7526.

Woychik, J. H. 1992. Preparation of simulated human milk protein by low temperature microfiltration. US patent no. 5169666. Inventor: J. H. Woychik, Lafayette Hill, PA. Assignee: The United States of America as represented by the Secretary of Agriculture, Washington, DC.

Zulewska, J., and D. M. Barbano. 2013. Influence of casein on flux and passage of serum proteins during microfiltration using polymeric spiral-wound membranes at $50^{\circ}$ C. J. Dairy Sci. 96:2048-2060.

Zulewska, J., and D. M. Barbano. 2014. The effect of linear velocity and flux on performance of ceramic graded permeability membranes when processing skim milk at $50^{\circ} \mathrm{C}$. J. Dairy Sci. 97:26192632.

Zulewska, J., M. W. Newbold, and D. M. Barbano. 2009. Efficiency of serum protein removal from skim milk with ceramic and polymeric membranes at $50^{\circ}$ C. J. Dairy Sci. 92:1361-1377. 